\title{
Aplikasi Deteksi Dini Plagiarisme Judul Tugas Akhir Mahasiswa Sekolah Tinggi Ilmu Kesehatan Yayasan Rs. Islam Surabaya Dengan Algoritma Rabin-Karp
}

\author{
Drajad Uji Cahyono
}

Universitas Nahdlatul Ulama Surabaya

E-mail:drajat@unusa.ac.id

\begin{abstract}
Abstrak
Di zaman modern yang serba instan dan cepat, dimana semakin mudahnya pertukaran informasi dewasa ini tidak hanya membawa dampak positif bagi kemajuan teknologi, tetapi juga membawa dampak negatif yang hampir tidak dapat dihindari yaitu plagiarisme. Praktek plagiarisme ini sangat sering dilakukan terutama di kalangan akademisi baik di tingkat sekolah maupun di perguruan tinggi. Alhasil, tindakan plagiarisme ini dapat berdampak pada penurunan kreatifitas siswa maupun mahasiswa. Berbagai cara persuasif oleh perguruan tinggi diupayakan bagi mahasiswa untuk mencegah kemungkinan dilakukannya kegiatan plagiarisme. Berdasarkan permasalahan tersebut maka, skripsi ini ditujukan untuk membuat suatu Aplikasi Deteksi Dini Plagiarisme Judul Tugas Akhir Mahasiswa STIKES Yayasan RS. Islam Surabaya dengan Algoritma Rabin-Karp. Metode yang digunakan dalam aplikasi ini yaitu dengan membandingkan kemiripan judul tugas akhir yang telah ada di database dengan judul tugas akhir yang tengah diajukan oleh mahasiswa. Dengan adanya aplikasi ini sekumpulan judul tugas akhir dapat diuji apakah antar judul tugas akhir memiliki kesamaan atau tidak. Berdasarkan hasil evaluasi uji coba sistem dapat diketahui bahwa performa hasil persentase similaritas dari algoritma Rabin-Karp memiliki ketergantungan dengan nilai Kgram yang diberikan. Berikutnya, hasil pengujian akurasi pada pendeteksian similaritas judul tugas akhir diperoleh hasil rata-rata akurasi similaritas adalah sebesar 63,19 \%. Algoritma Rabin-Karp masih cukup layak untuk digunakan sebagai suatu metode sederhana untuk mendeteksi kemungkinan terjadinya plagiarisme. Meski begitu, aplikasi ini belum dapat digunakan secara sempurna untuk memastikan kemungkinan akan terjadinya tindakan plagiarisme tugas akhir. Tujuan akhir yang diharapkan adalah dengan adanya aplikasi ini kemungkinan akan dilakukannya praktek plagiarisme dapat dideteksi dan dicegah sedini mungkin.
\end{abstract}

Kata Kunci: Plagiarisme, String Matching, Rabin-Karp

\section{PENDAhuluan}

Teknologi saat ini berkembang dengan sedemikian pesatnya, utamanya dalama hal pertukaran informasi. Di zaman modern yang serba instan dan cepat ini, semakin mudah pertukaran informasi dewasa ini tidak hanya membawa dampak positif bagi kemajuan teknologi, tetapi juga membawa dampak negatif yang hampir tidak dapat dihindari yaitu plagiarisme. Praktek plagiarisme ini sangat sering dilakukan terutama di kalangan akademisi baik sekolah maupun di perguruan tinggi. Alhasil, tindakan plagiarisme ini dapat berdampak pada penurunan kreatifitas siswa maupun mahasiswa.

Sebagai salah satu peguruan tinggi, Sekolah Tinggi Ilmu Kesehatan Yayasan Rumah Sakit Islam Surabaya (STIKES YARSIS) juga berupaya semaksimal mungkin untuk mencegah terjadinya plagiarisme. Embrio lembaga pendidikan tenaga kesehatan perawat dan bidan ini sudah ada sejak tahun 1979, sehingga saat ini telah meluluskan ribuan tenaga perawat dan bidan. Dengan rentang waktu penyelenggaraan pendidikan yang telah begitu lama dan tidak dapat dipungkiri 
hasil karya tugas akhir mahasiswa-pun berjumlah sangat banyak, sehingga dapat menjadi sasaran empuk bagi upaya-upaya plagiarisme.

Upaya-upaya persuasif seperti tersebut diatas juga selalu dilakukan oleh STIKES YARSIS, dibarengi dengan sistem kontrol melalui koordinator tugas akhir yang ditunjuk pada tiap-tiap program studi. Akan tetapi koordinator tugas akhir hingga saat ini belum memiliki sarana yang memadai untuk mendeteksi kemungkinan-kemungkinan dilakukannya plagiarisme. Oleh karena itu untuk mencegah praktik plagiarisme tersebut diperlukan sistem deteksi dini pengukuran tingkat similaritas tugas akhir mahasiswa.

Berdasarkan permasalahan tersebut maka akan dirancang dan dibangun suatu "Aplikasi Deteksi Dini Plagiarisme Judul Tugas Akhir Mahasiswa Sekolah Tinggi Ilmu Kesehatan Yayasan RS. Islam Surabaya dengan Algoritma Rabin-Karp". Teknik yang digunakan dalam perancangan aplikasi yaitu dengan membandingkan kemiripan judul tugas akhir yang telah ada dengan judul tugas akhir yang tengah diajukan oleh mahasiswa.

Dengan adanya aplikasi ini sekumpulan judul tugas akhir dapat diuji apakah antar judul tugas akhir dan yang lainnya memiliki kesamaan atau tidak, diharapkan dengan adanya aplikasi ini kemungkinan akan dilakukannya praktek plagiarisme dapat dideteksi dan dicegah sedini mungkin.

\section{LANDASAN TEORI}

a. Plagiarisme

Plagiarisme, menurut Kamus Besar Bahasa Indonesia, ialah penjiplakan yang melanggar hak cipta, yaitu hak seseorang atas hasil penemuannya yang dilindungi oleh undang-undang. Plagiat adalah pengambilan karangan (pendapat, dsb) orang lain dan menjadikannya seolaholah karangan / pendapat sendiri, misalnya menerbitkan karya tulis orang lain atas nama dirinya sendiri. Orang yang melakukan plagiat disebut plagiator atau penjiplak.

b. Metode Pendeteksian Plagiarisme

Metode pendeteksi plagiarisme dibagi menjadi tiga bagian yaitu metode perbandingan teks lengkap, metode dokumen fingerprinting, dan metode kesamaan kata kunci.



Gambar 1. Metode Pendeteksian Plagiarisme

Berikut ini pejelasan dari masing-masing metode dan algoritma yang digunakan dalam sistem ini:

a. Perbandingan teks lengkap. Metode ini diterapkan dengan membandingkan semua isi dokumen. Dapat diterapkan untuk dokumen yang besar. Pendekatan ini membutuhkan waktu yang lama tetapi cukup efektif, karena kumpulan dokumen yang diperbandingkan adalah dokumen yang disimpan pada penyimpanan lokal. Metode perbandingan teks lengkap tidak dapat diterapkan untuk kumpulan dokumen yang tidak terdapat pada 
dokumen lokal. Algoritma yang digunakan pada metode ini adalah algoritma Brute-Force, algoritma Edit Distance, algoritma Boyer Moore dan algoritma Lavenshtein Distance.

b. Dokumen Fingerprinting. Dokumen fingerprinting merupakan metode yang digunakan untuk mendeteksi keakuratan salinan antar dokumen, baik semua teks yang terdapat di dalam dokumen atau hanya sebagian teks saja. Prinsip kerja dari metode dokumen fingerprinting ini adalah dengan menggunakan teknik hashing. Teknik hashing adalah sebuah fungsi yang mengkonversi setiap string menjadi bilangan. Misalnya Rabin-Karp, Winnowing dan Manber

c. Kesamaan kata kunci. Prinsip dari metode ini adalah mengekstrak kata kunci dari dokumen dan kemudian dibandingkan dengan kata kunci pada dokumen yang lain. Pendekatan yang digunakan pada metode ini adalah teknik dot.

c. Algoritma Rabin-Karp

Algoritma Karp-Rabin diciptakan oleh Michael O. Rabin dan Richard M. Karp pada tahun 1987 yang menggunakan fungsi hashing untuk menemukan pattern di dalam string teks. Fungsi hashing menyediakan metode sederhana untuk menghindari perbandingan jumlah karakter yang quadratik di dalam banyak kasus atau situasi. Daripada melakukan pemeriksaan terhadap setiap posisi dari teks ketika terjadi pencocokan pola, akan lebih baik efisien untuk melakukan pemeriksaan hanya jika teks yang sedang proses memiliki kemiripan seperti pada pattern. Untuk melakukan pengecekan kemiripan antara dua kata ini digunakan fungsi hash. Algoritma Rabin-Karp ini banyak digunakan dalam pendeteksian pencontekan atau kecurangan.

d. Preprocessing Data

Sebelum menentukan fitur-fitur yang mewakili, diperlukan tahap preprocessing yang dilakukan secara umum dalam teks mining pada dokumen, yaitu case folding dan tokenizing.

a. Case Folding

Case folding adalah mengubah semua huruf dalam dokumen menjadi huruf kecil. Hanya huruf "a" sampai dengan "z" yang diterima.

b. Tokenizing

Tahap tokenizing / parsing adalah tahap pemotongan string input berdasarkan tiap kata yang menyusunnya. Karakter selain huruf dihilangkan dan dianggap delimiter.

c. K-gram

K-gram adalah rangkaian terms dengan panjang K. Kebanyakan yang digunakan sebagai terms adalah kata. K-gram merupakan sebuah metode yang diaplikasikan untuk pembangkitan kata atau karakter. Metode K-gram ini digunakan untuk mengambil potongan-potongan karakter huruf sejumlah $\mathrm{k}$ dari sebuah kata yang secara kontinuitas dibaca dari teks sumber hingga akhir dari dokumen.

d. Hashing

Hashing adalah suatu cara untuk mentransformasi sebuah string menjadi suatu nilai yang unik dengan panjang tertentu (fixed-length) yang berfungsi sebagai penanda string tersebut. Fungsi untuk menghasilkan nilai ini disebut fungsi hash sedangkan nilai yang dihasilkan disebut nilai hash.

e. Pengukuran Nilai Similaritas

Inti dari pendekatan k-gram dibagi menjadi dua tahap. Tahap pertama, membagi kata menjadi k-gram. Kedua, mengelompokkan hasil terms dari k-gram yang sama. Kemudian untuk menghitung similarity dari kumpulan kata tersebut maka digunakan rumus pengukuran nilai similaritas untuk pasangan kata yang digunakan. 


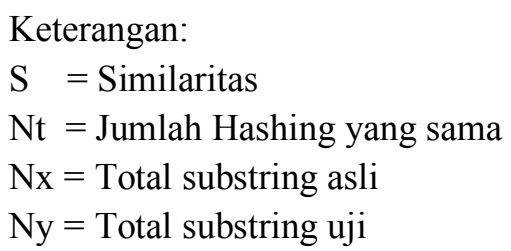

\section{ANALISIS DAN PERANCANGAN SISTEM}

a. Analisis Masalah

Sebelum adanya aplikasi ini, usaha upaya untuk mendeteksi kesamaan judul dilakukan dengan menggunakan fasilitas pencarian database tugas akhir di perpustakaan. Dimana teknik tersebut masih membutuhkan "tenaga ekstra" bagi panitia tugas akhir (koordinator) untuk memutuskan apakah suatu judul tugas akhir yang diajukan oleh mahasiswa layak digunakan lebih lanjut atau tidak. Dengan adanya aplikasi ini diharapkan kemungkinan tindakan plagiarisme dapat dideteksi dan dicegah sedini mungkin.



Gambar 2. Aplikasi Deteksi Dini Plagiarism

b. Perancangan Sistem

Aplikasi yang akan dibuat adalah untuk mengetahui tingkat similiaritas judul tugas akhir sehingga dapat digunakan sebagai salah satu sarana untuk mendeteksi secara dini kemungkinan dilakukannya plagiarisme. Pengguna akan menginputkan judul tugas akhir, setelah itu sistem akan menguji berapa persen hasil tingkat similaritas judul yang diajukan dengan database yang ada.

Setelah sistem memperoleh data inputan, selanjutnya sistem akan masuk ke tahap string tokenizing. Proses tokenizing merupakan penghilangan kata dan tanda baca yang dianggap kurang penting seperti kata penghubung (yang, dan, di, dll) serta karakter tanda titik, koma dan sebagainya. Selain itu pada tahapan ini string yang diolah disamaratakan menjadi lower case seluruhnya. Berikut contoh yang judul tugas akhir yang belum dilakukan tokenizing: "Perbedaan perkembangan motorik kasar anak usia Todler (1-3 tahun) pada ibu bekerja dan tidak bekerja di Posyandu Pondok Candra Sidoarjo". Setelah dilakukan tokenizing akan menjadi seperti ini: "perbedaan perkembangan motorik kasar anak usia todler 1-3 tahun pada ibu bekerja tidak bekerja posyandu pondok candra sidoarjo".

Tahapan berikutnya setelah string tokenizing adalah melakukan parsing k-gram yakni memecah kata yang telah diproses string tokenizing menjadi potongan-potongan dimana setiap 
potongan mengandung string karakter sebanyak k. Setelah melakukan parsing k-gram langkah berikutnya adalah menghitung nilai hashing dari tiap potongan string. Setelah itu langkah berikutnya adalah melakukan hash matching yakni pencocokan nilai hash dari keseluruhan potongan string yang dibandingkan. Proses akhir adalah menghitung banyaknya nilai hash string yang sama sehingga didapatkan hasil persentase similaritasnya. Berikut diagram fungsi algoritma yang digunakan.

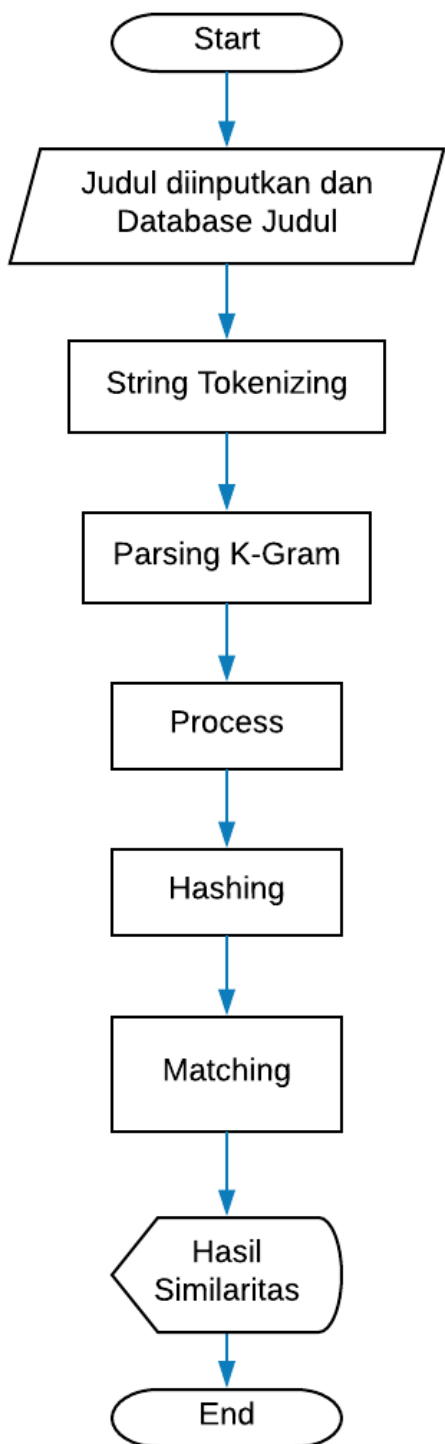

Gambar 3. Proses Menghitung Nilai Similaritas Judul

c. Perhitungan Manual

Untuk lebih jelas mengenai proses menghitung nilai persentase similaritas judul makan akan diperlihatkan contoh kasus sederhana dan cara menghitungnya dengan cara manual sebagai berikut:

Teks 1 : Saya Drajad.

Teks 2 : Saya Andrea.

a. Tokenizing

Setelah dilakukan tokenizing, kalimatnya akan menjadi seperti ini:

Teks 1 : saya drajad

Teks 2 : saya andrea 
b. Parsing K-Gram

Pembagian string berdasarkan K-Gram. Nilai K-Gram yang digunakan adalah 4 (KGram=4). Maka string tersebut akan menjadi potongan string seperti di bawah ini: $\{$ saya $\}\{$ aya $\}\{$ ya $a\}\{$ a an $\}\{$ and $\}\{$ andr $\}\{$ ndre $\}\{$ drea $\}$

Tabel 1. Tabel Perbandingan String Teks 1 dan Teks 2

\begin{tabular}{|l|l|}
\hline \multicolumn{2}{|c|}{ Teks 1 } \\
\hline No & \multicolumn{1}{|c|}{ Substring } \\
\hline 1 & saya \\
\hline 2 & aya \\
\hline 3 & ya d \\
\hline 4 & a dr \\
\hline 5 & dra \\
\hline 6 & draj \\
\hline 7 & raja \\
\hline 8 & ajad \\
\hline
\end{tabular}

\begin{tabular}{|l|l|}
\hline \multicolumn{2}{|c|}{ Teks 2 } \\
\hline No & \multicolumn{1}{|c|}{ Substring } \\
\hline 1 & saya \\
\hline 2 & aya \\
\hline 3 & ya a \\
\hline 4 & a an \\
\hline 5 & and \\
\hline 6 & andr \\
\hline 7 & ndre \\
\hline 8 & drea \\
\hline
\end{tabular}

c. Hashing

Merupakan proses pengubahan karakter menjadi bilangan hash. Untuk melakukan pengubahan tersebut digunakan rumus sebagai berikut.

$$
\mathrm{H}=\mathrm{C} 1 * \mathrm{a}(\mathrm{k}-1)+\mathrm{C} 2 * \mathrm{a}(\mathrm{k}-2)+\mathrm{C} 3 * \mathrm{a}(\mathrm{k}-3) \ldots+\mathrm{Ck}^{*} \mathrm{a} 0
$$

Dimana $\mathrm{H}$ adalah nilai Hash, $\mathrm{C}$ adalah nilai ASCII untuk suatu karakter, a adalah bilangan basis, sedangkan $\mathrm{k}$ adalah banyaknya karakter.

Pola: "saya"

Nilai Hash dari saya $=\mathrm{s}^{*} 113+\mathrm{a}^{*} 112+\mathrm{y} * 111+\mathrm{a} * 110$

$$
\begin{aligned}
& =115^{*} 113+97 * 112+121 * 111+97 * 110 \\
& =166230
\end{aligned}
$$

Dengan melakukan perhitungan yang sama terhadap kalimat yang telah di K-Gram maka di dapat nilai hashing sebagai berikut. Tabel Perbandingan Teks 1 dan Teks 2 Setelah Nilai Hash Didapatkan.

Tabel 2. Tabel Nilai Hash Perbandingan Teks 1 dan Teks 2

\begin{tabular}{|l|l|l|}
\hline No & Teks1 & Hash \\
\hline $\mathbf{1}$ & saya & $\mathbf{1 6 6 2 3 0}$ \\
\hline $\mathbf{2}$ & aya & $\mathbf{1 4 4 8 4 7}$ \\
\hline 3 & ya d & 173240 \\
\hline 4 & a dr & 134193 \\
\hline 5 & dra & 56043 \\
\hline 6 & draj & 148067 \\
\hline 7 & raja & 164734 \\
\hline 8 & ajad & 143100 \\
\hline
\end{tabular}

\begin{tabular}{|l|l|c|}
\hline No & Teks 2 & Hash \\
\hline $\mathbf{1}$ & saya & $\mathbf{1 6 6 2 3 0}$ \\
\hline $\mathbf{2}$ & aya & $\mathbf{1 4 4 8 4 7}$ \\
\hline 3 & Ya a & 173237 \\
\hline 4 & a an & 134156 \\
\hline 5 & and & 55639 \\
\hline 6 & andr & 143631 \\
\hline 7 & ndre & 159865 \\
\hline 8 & drea & 148102 \\
\hline
\end{tabular}

Keterangan Bold: nilai hash sama 
Setelah didapatkan nilai hash dari seluruh substring, kemudian dicari nilai hash yang sama dari kedua teks. Seperti nilai hash yang diberikan keterangan Bold (ditebalkan) pada tabel diatas.

d. Pencocokan Nilai Hashing

Dengan cara mencocokan satu per satu dari kedua tabel nilai hash, dihitung jumlah hash yang sama. Seperti pada tabel di awah ini.

Tabel 3. Tabel Pencocokan Nilai Hash

\begin{tabular}{|c|c|c|}
\hline Teks 1 & Hasil & Teks 2 \\
\hline $\mathbf{1 6 6 2 3 0}$ & $=$ & $\mathbf{1 6 6 2 3 0}$ \\
\hline $\mathbf{1 4 4 8 4 7}$ & $=$ & $\mathbf{1 4 4 8 4 7}$ \\
\hline 173240 & $\neq$ & 173237 \\
\hline 134193 & $\neq$ & 134156 \\
\hline 56043 & $\neq$ & 55639 \\
\hline 148067 & $\neq$ & 143631 \\
\hline 164734 & $\neq$ & 159865 \\
\hline 143100 & $\neq$ & 148102 \\
\hline
\end{tabular}

Dengan cara yang sama dilakukan pencocokan terhadap semua nilai hash satu persatu.

e. Pengukuran Nilai Similaritas

Dengan menggunakan rumus dibawah ini:

$$
\mathrm{S}=\frac{N t}{N x+N y}
$$

Dimana S adalah nilai Similaritas yang akan dicari, Nt adalah Jumlah K-Gram Nilai Hash yang sama dan $\mathrm{Nx}+\mathrm{Ny}$ adalah total jumlah K-Gram dari 2 string yang dibandingkan. Maka hasil yang didapatkan adalah:

$$
\begin{gathered}
S=\frac{4}{8+8} \\
S=0,25
\end{gathered}
$$

Untuk mendapatkan persentase similaritas, dikalikan dengan persen. Jadi tingkat similaritas string yang diuji yakni $=25 \%$.

\section{IMPLEMENTASI DAN PENGUJIAN}

Pengujian performansi pada akurasi pendeteksian judul-judul tugas akhir yang memiliki tingkat similaritas cukup tinggi, dimana pada pengujian ini akan mencoba membandingkan beberapa judul tugas akhir yang hampir mirip dengan cara merubah parameter k-gram mulai dengan nilai satu sampai dengan sepuluh. Judul tugas akhir yang akan diuji berikut ini merupakan judul tugas akhir yang telah ada di STIKES YARSIS.

Pengujian dengan judul tugas akhir, sebagai berikut:

Judul Tugas Akhir : FAKTOR-FAKTOR YANG MEMPENGARUHI IBU DALAM MEMILIH KB SUNTIK 3 BULAN DI BPS SITI HASUNAH DESA DURUNG BEDUG KECAMATAN CANDI SIDOARJO, dengan:

Judul Tugas Akhir $\quad$ : FAKTOR-FAKTOR YANG MEMPENGARUHI IBU DALAM MEMILIH KB SUNTIK 3 BULAN DI BPS SUTIYANI DESA BABAN KABUPATEN SUMENEP MADURA 
Berikut hasil perhitungan yang dihasilkan:

Tabel 4. Pengujian Performa Algoritma Rabin Karp

\begin{tabular}{|c|c|c|}
\hline No & K-Gram & Similaritas \\
\hline 1 & 1 & $93.02 \%$ \\
\hline 2 & 2 & $78.48 \%$ \\
\hline 3 & 3 & $62.86 \%$ \\
\hline 4 & 4 & $60.27 \%$ \\
\hline 5 & 5 & $58.56 \%$ \\
\hline 6 & 6 & $57.40 \%$ \\
\hline 7 & 7 & $58.72 \%$ \\
\hline 8 & 8 & $56.50 \%$ \\
\hline 9 & 9 & $56.11 \%$ \\
\hline 10 & 10 & $55.71 \%$ \\
\hline
\end{tabular}

Sedangkan pada pengujian akurasi similaritas judul tugas akhir dengan membandingkan beberapa judul, diperoleh hasil sebagai berikut:

Tabel 5. Pengujian Akurasi Similaritas Judul Tugas Akhir

\begin{tabular}{|c|c|c|c|}
\hline No & Judul 1 & Judul 2 & Similaritas \\
\hline 1 & $\begin{array}{l}\text { Faktor-faktor yang } \\
\text { mempengaruhi ibu dalam } \\
\text { memilih KB suntik } 3 \text { bulan di } \\
\text { BPS Siti Hasunah Desa Durung } \\
\text { Bedug Kecamatan Candi } \\
\text { Sidoarjo }\end{array}$ & $\begin{array}{l}\text { Faktor-faktor yang } \\
\text { mempengaruhi ibu dalam } \\
\text { memilih KB suntik } 3 \text { bulan di } \\
\text { BPS Sutiyani Desa Baban } \\
\text { Kabupaten Sumenep Madura }\end{array}$ & $60.27 \%$ \\
\hline 2 & $\begin{array}{l}\text { Gambaran tingkat pengetahuan } \\
\text { masyarakat tentang upaya } \\
\text { pencegahan penyakit demam } \\
\text { berdarah di RW 05 Desa } \\
\text { Kapasan Kelurahan Sidokare } \\
\text { Kecamatan Sidoarjo }\end{array}$ & $\begin{array}{l}\text { Gambaran tingkat pengetahuan } \\
\text { masyarakat tentang tanda dan } \\
\text { gejala penyakit demam berdarah } \\
\text { di RW 05 Desa Kapasan } \\
\text { Kelurahan Sidokare Kecamatan } \\
\text { Sidoarjo }\end{array}$ & $88.81 \%$ \\
\hline 3 & $\begin{array}{l}\text { Hubungan tingkat pengetahuan } \\
\text { tentang penyakit menular } \\
\text { seksual dengan sikap remaja } \\
\text { pada siswa SMA XXX Kelas } \\
\text { XXX }\end{array}$ & $\begin{array}{l}\text { Gambaran pengetahuan tentang } \\
\text { penyakit menular seksual pada } \\
\text { remaja di Desa Karang Tanjung } \\
\text { Kecamatan Candi Kabupaten } \\
\text { Sidoarjo }\end{array}$ & $47.00 \%$ \\
\hline 4 & $\begin{array}{l}\text { Hubungan antara konsep diri } \\
\text { dengan kejadian kenakalan } \\
\text { remaja pada siswa kelas } 2 \text { di } \\
\text { Smu Wachid Hasyim } 2 \text { YPM } \\
\text { Taman Sepanjang }\end{array}$ & $\begin{array}{l}\text { Hubungan konsep diri dengan } \\
\text { kejadian kenakalan remaja pada } \\
\text { siswa kelas VIII di SMP Bina } \\
\text { Bangsa Surabaya }\end{array}$ & $61.17 \%$ \\
\hline 5 & $\begin{array}{l}\text { Hubungan antara tingkat } \\
\text { pengetahuan ibu tentang } \\
\text { pentingnya antenatal care } \\
\text { dengan keteraturan antenatal }\end{array}$ & $\begin{array}{l}\text { Hubungan pengetahuan ibu } \\
\text { hamil tentang antenatal care } \\
\text { dengan keteraturan antenatal } \\
\text { care di Polindes Banjar Timur }\end{array}$ & $47.24 \%$ \\
\hline
\end{tabular}




\begin{tabular}{|l|l|l|c|}
\hline No & \multicolumn{1}{|c|}{ Judul 1 } & \multicolumn{1}{|c|}{ Judul 2 } & Similaritas \\
\hline & $\begin{array}{l}\text { care di BPS Mimiek Andayani } \\
\text { Simo Pomahan Surabaya }\end{array}$ & $\begin{array}{l}\text { Kecamatan Gapura Kabupaten } \\
\text { Sumenep }\end{array}$ & \\
\hline 6 & $\begin{array}{l}\text { Hubungan perawatan payudara } \\
\text { dengan kelancaran ASI pada ibu } \\
\text { nifas di BPS Aski Surabaya }\end{array}$ & $\begin{array}{l}\text { Hubungan antara perawatan } \\
\text { payudara pada ibu nifas dengan } \\
\text { kelancaran ASI di BPS Yayuk } \\
\text { Ismail Jagir Surabaya }\end{array}$ & $72.51 \%$ \\
\hline 7 & $\begin{array}{l}\text { Hubungan antara tingkat } \\
\text { pengetahuan ibu dengan } \\
\text { pemberian makanan pendamping } \\
\text { ASI pada bayi usia 0-6 bulan di } \\
\text { Desa Durung Bedug Kecamatan } \\
\text { Candi Kabupaten Sidoarjo }\end{array}$ & $\begin{array}{l}\text { Gambaran tingkat pengetahuan } \\
\text { ibu tentang pemberian makanan } \\
\text { pendamping ASI pada bayi usia } \\
\text { 0-6 bulan di Puskesmas } \\
\text { Pembantu Sumberjo Pucuk } \\
\text { Kabupaten Lamongan }\end{array}$ & $58.98 \%$ \\
\hline 8 & $\begin{array}{l}\text { Hubungan antara peran keluarga } \\
\text { dengan kepatuhan minum obat } \\
\text { pada penderita TB Paru di } \\
\text { Puskesmas Perak Timur } \\
\text { Surabaya }\end{array}$ & $\begin{array}{l}\text { Hubungan dukungan keluarga } \\
\text { dengan kepatuhan minum obat } \\
\text { pada penderita TB Paru di } \\
\text { Puskesmas Tulangan Kabupaten } \\
\text { Sidoarjo }\end{array}$ & $70.87 \%$ \\
\hline 9 & $\begin{array}{l}\text { Gambaran tingkat pengetahuan } \\
\text { ibu menyusui tentang teknik } \\
\text { menyusui yang benar di BPS. Hj } \\
\text { Soedarti Gasmanan Surabaya }\end{array}$ & $\begin{array}{l}\text { Gambaran pengetahuan ibu } \\
\text { menyusui tentang teknik } \\
\text { menyusui yang benar di RT 04 } \\
\text { RW 03 Kelurahan Wonokromo }\end{array}$ & $59.02 \%$ \\
\hline 10 & $\begin{array}{l}\text { Hubungan antara tingkat } \\
\text { pengetahuan remaja tentang } \\
\text { kesehatan reproduksi dengan } \\
\text { perilaku seks bebas pada siswa } \\
\text { kelas X di SMA Giki 2 Surabaya }\end{array}$ & $\begin{array}{l}\text { Hubungan tingkat pengetahuan } \\
\text { kesehatan reproduksi dengan } \\
\text { perilaku seks bebas remaja di } \\
\text { SMAN 1 Parengan Tuban }\end{array}$ & $66.08 \%$ \\
\hline
\end{tabular}

\section{KESIMPULAN DAN SARAN}

Pada bab ini akan dijelaskan mengenai kesimpulan yang berisi hasil-hasil yang diperoleh setelah dilakukan analisis, desain, implementasi dan pengujian dari perangkat lunak yang dibangun dan telah dikembangkan serta saran-saran yang akan memberikan catatan penting dan kemungkinan perbaikan yang diperlukan untuk pengembangan perangkat lunak selanjutnya.

\section{Kesimpulan}

a. Aplikasi deteksi dini plagiarisme tugas akhir sudah cukup mudah untuk digunakan.

b. Berdasarkan hasil evaluasi uji coba sistem dapat diketahui bahwa performa hasil persentase similaritas dari algoritma Rabin-Karp memiliki ketergantungan dengan nilai K-gram yang diberikan.

c. Berdasarkan hasil pengujian akurasi pada pendeteksian similaritas judul tugas akhir diperoleh hasil rata-rata akurasi similaritas adalah sebesar 63,19\%.

d. Algoritma Rabin-Karp cukup layak untuk digunakan sebagai suatu metode sederhana untuk mendeteksi secara dini kemungkinan terjadinya plagiarisme. Akan tetapi, aplikasi ini belum dapat digunakan secara sempurna untuk memastikan kemungkinan akan terjadinya tindakan plagiarisme tugas akhir. 


\section{Saran}

Dalam penyusunan penelitian ini, masih terdapat banyak kekurangan yang sangat memungkinkan untuk diperbaiki dan disempurnakan pada pengembangan selanjutnya. Beberapa saran yang dapat diberikan untuk pengembangan adalah:

1. Aplikasi ini diharapkan dapat membantu untuk mencegah secara dini kemungkinan terjadinya kegiatan plagiarisme dalam pengerjaan tugas akhir mahasiswa.

2. Aplikasi ini akan lebih bagus jika dapat menggunakan persamaan makna sinonim kata dalam implementasinya.

3. Aplikasi ini perlu disempurnakan dengan penambahan fasilitas untuk mendeteksi plagiarisme langsung pada dokumen tugas akhir, sehingga akurasi ada atau tidaknya suatu kegiatan plagiarisme dapat diukur secara pasti.

\section{DAFTAR PUSTAKA}

[1] Chillar, Rajender Singh dan Kochar, Barjes. RB-Matcher: String Matching Technique. World Academy Of Science, Engeneering and Technology. 2008; 18. 132-135

[2] Sandi H. Trik dan Solusi Jitu Pemrograman Web. Yogyakarta: Penerbit Lokomedia. 2010.

[3] Abdul K. Konsep \& Tuntunan Praktis Basis Data. Yogyakarta: Penerbit Andi.1999.

[4] Abdul Kadir. Tuntunan Praktis Belajar Database Menggunakan MySQL. Yogyakarta: Andi Offset. 2008.

[5] Sarwo P. Yii Framework: Menguasai Framework PHP Terbaik. Yogyakarta: Penerbit Lokomedia. 2013.

[6] Pusat Bahasa Departemen Pendidikan Nasional (2008).

http://bahasa.kemdiknas.go.id/kbbi/index.php

[7] Ade Mirza S. Perancangan Sistem Penentuan Similarity Kode Program pada Bahasa C dan Pascal dengan Menggunakan Algoritma Rabin-Karp. Fakultas Teknik Universitas Tanjung Pura: Program Studi Teknik Informatika. 2013.

[8] Taufik, Dennis Ahmad. Sistem Pengukuran Tingkat Similaritas Dokumen. Bandung: Universitas Komputer Indonesia. 2012. 